\title{
PEMANFAATAN PEKARANGAN UNTUK BUDIDAYA TANAMAN OLERIKULTURA SEBAGAI PENDUKUNG KETAHANAN PANGAN PADA ERA PANDEMI COVID-19 DI DESA PETUDUA
}

\author{
Juniaty Arruan Bulawan ${ }^{1 *}$, Hasbiadi' ${ }^{2}$, La Mpia ${ }^{3}$, Fitrianti Handayani ${ }^{4}$ \\ 1,2,3,4 Universitas Sembilanbelas November, Kolaka, Indonesia \\ *Penulis Koresponsensi, email: juniatyusn@gmail.com
}

Received:06/01/2022

Revised:13/01/2022

Accepted:25/01/2021

\begin{abstract}
The people of Petudua Village on average have a large yard of land, but it has not been used properly. Therefore, the village government facilitates the community by providing various types of olericultural plant seeds or vegetables, to help meet daily nutritional needs, especially during the Covid-19 pandemic. However, the community does not yet know how to cultivate plants properly, so it is necessary to provide assistance in the use of the yard. This service activity aims to assist the Petudua village community to increase knowledge about good plant cultivation, and provide motivation to the community to be able to use their yards to support the availability of family food. The stages of the activities carried out included counseling on the benefits of plant cultivation in the yard, training on how to sow seeds, and training in making organic fertilizers and pesticides from onion skins. The result of this activity is an increase in public knowledge about how to cultivate plants, good nurseries, and how to make organic fertilizers and pesticides from onion skins and can be applied to their respective yards. It is hoped that the Petudua Village government will continue this program, to support food security and improve community welfare.
\end{abstract}

Keywords: Yard, olericultural plant, food security, covid-19 pandemic

Abstrak. Masyarakat Desa Petudua rata-rata memiliki lahan pekarangan yang luas, namun belum dimanfaatkan dengan baik. Olehnya itu pemerintah desa memfasilitasi masyarakat dengan memberikan berbagai jenis benih tanaman olerikultura atau sayur-sayuran untuk membantu memenuhi kebutuhan gizi sehari-hari, khususnya pada masa pandemi Covid-19. Namun, masyarakat belum mengetahui cara budidaya tanaman dengan baik, sehingga perlu dilakukan pendampingan pemanfaatan pekarangan. Kegiatan pengabdian ini bertujuan untuk mendampingi masyarakat desa Petudua dalam meningkatkan pengetahuan mengenai cara budidaya tanaman yang baik, dan memberikan motivasi kepada masyarakat agar dapat memanfaatkan lahan pekarangan untuk mendukung ketersediaan pangan keluarga dan memanfaatkan limbah rumah tangga khususnya kulit bawang untuk diolah menjadi pupuk sekaligus pestisida organik. Tahapan kegiatan yang dilakukan meliputi penyuluhan manfaat budidaya tanaman di pekarangan, pelatihan cara menyemaikan bibit, serta pelatihan pembuatan pupuk dan pestisida organik dari kulit bawang. Hasil dari kegiatan ini adalah meningkatnya pengetahuan masyarakat tentang cara budidaya tanaman, cara pembibitan yang baik, serta cara pembuatan pupuk dan pestisida organik dari kulit bawang dan dapat diaplikasikan pada pekarangan masing-masing. Diharapkan agar pemerintah Desa Petudua terus melanjutkan program ini, untuk mendukung ketahanan pangan dan meningkatkan kesejahteraan masyarakat.

Kata Kunci: Pemanfaatan pekarangan, tanaman olerikultura, ketahanan pangan, pandemi Covid-19

How to Cite: Bulawan, J. A., Hasbiadi, H., Mpia, L., \& Handayani, F. (2022). Pemanfaatan Pekarangan untuk Budidaya Tanaman Olerikultura sebagai Pendukung Ketahanan Pangan Pada Era Pandemi Covid-19 di Desa Petudua. Mitra Mahajana: Jurnal Pengabdian Masyarakat, 3(1), 50-56. doi: https://doi.org/10.37478/mahajana.v3i1.1537

\section{PENDAHULUAN}

Pandemi virus Covid-19 menjadikan masyarakat berupaya menciptakan kemandirian pangan untuk memenuhi kebutuhan gizi keluarga sehari-hari. Mengonsumsi sayur-sayuran setiap hari dapat memberikan banyak manfaat bagi tubuh manusia, karena merupakan sumber vitamin dan serat serta antioksidan yang dapat menjaga kekebalan tubuh. Jenis sayuran hijau yang terdapat di Desa Petudua sangat terbatas jumlahnya seperti daun singkong, daun labu kuning dan beberapa jenis tumbuhan lokal yang diolah menjadi sayur untuk memenuhi kebutuhan sehari-hari. Sedangkan untuk memperoleh jenis sayuran seperti kangkung, sawi, bayam, dan kacang panjang, masyarakat harus mengeluarkan uang dan membeli di pasar tradisional ataupun penjual sayur keliling. Tetapi saat ini masyarakat mengurangi konsumsi sayuran hijau karena faktor ekonomi yang tidak stabil akibat adanya pandemi covid-19. Hasil penelitian Aisyah (2020) terhadap ketahanan pangan keluarga di masa pandemi menunjukkan 
adanya rasa khawatir terhadap kecukupan bahan pangan, sehingga terdapat masyarakat yang melakukan pengurangan terhadap jumlah pangan, agar mampu bertahan selama pandemi belum berakhir. Hal ini justru akan mengakibatkan kekebalan tubuh menurun karena asupan vitamin menjadi berkurang. Menurut Sekarindah (2008) kurangnya konsumsi terhadap sayuran dan buah dapat menyebabkan tubuh kekurangan vitamin, mineral, serat, dan asam basa tubuh menjadi tidak seimbang, dan dapat menimbulkan berbagai jenis penyakit. Simanjuntak dan Erwinsyah (2020) juga menyatakan bahwa keadaan ini malah akan menjadikan masyarakat mengalami kekurangan nutrisi dan menurunkan sistem kekebalan tubuh.

Salah satu upaya untuk mendukung ketersediaan pangan khususnya sayuran sebagai penyedia gizi sehat keluarga di masa pandemi adalah dengan memanfaatkan pekarangan untuk budidaya berbagai jenis tanaman. Pekarangan adalah lahan yang berada di sekitar rumah atau tempat tinggal yang terletak di depan, di samping, ataupun dibelakang rumah. Pekarangan yang dimanfaatkan dengan baik dapat berfungsi sebagai lumbung hidup yang dapat menyediakan kebutuhan pangan pokok, seperti beras, jagung, umbi-umbian dan disebut apotik hidup karena dapat menyediakan bermacam-macam tanaman obat-obatan tradisional (Madyowati, 2017). Bahan pangan tersebut tersimpan di pekarangan masih dalam keadaan hidup. Warung hidup juga menjadi sebutan bagi pekarangan yang menyediakan berbagai jenis sayuran dan buahbuahan yang dapat dikonsumsi sehari-hari, bahkan dapat dijual sehingga disebut juga bank hidup (Ashari et al, 2012). Pekarangan juga dapat bermanfaat memberi keindahan di sekitar rumah pemiliknya, bahkan dapat mempererat hubungan sosial antar masyarakat yang bertetangga (Alhudhori, 2017). Seluruh pekarangan rumah tangga memiliki potensi yang sangat besar untuk dimanfaatkan dalam memenuhi kebutuhan pangan keluarga (Dwiratna et al, 2018). Pemanfaatan pekarangan secara maksimal dapat membantu mengurangi pengeluaran rumah tangga, sekaligus meningkatkan pendapatan dengan cara menjual hasil produksi dari pekarangan tersebut (Khomah dan Rhina, 2016).

Masyarakat Desa Petudua rata-rata memiliki pekarangan yang luas, namun belum dimanfaatkan dengan baik. Olehnya itu, pemerintah desa memfasilitasi masyarakat setempat dalam memanfaatkan pekarangan melalui budidaya tanaman olerikultura atau sayur-sayuran yang sangat dibutuhkan untuk konsumsi sehari-hari. Jenis-jenis benih yang dibagikan kepada masyarakat yaitu kangkung, sawi, kacang panjang, jagung manis, terong ungu, cabai, paria, dan bayam serta dilengkapi dengan polybag dan waring net. Menurut Solihin et al (2018) jenis tanaman yang paling cocok dibudidayakan di pekarangan adalah sayur-sayuran.

Namun, ada beberapa hal yang menjadi kendala yang dihadapi dalam program pemanfaatan pekarangan ini diantaranya masyarakat belum mengetahui cara budidaya tanaman dengan baik, bagaimana cara pemupukan yang baik, serta bagaimana cara pengendalian hama dan penyakit apabila menyerang tanaman budidaya. Kegiatan pengabdian kepada masyarakat ini bertujuan mendampingi masyarakat desa Petudua untuk meningkatkan pengetahuan mengenai cara budidaya tanaman yang baik, dan memberikan motivasi kepada masyarakat agar dapat memanfaatkan lahan pekarangan untuk mendukung ketersediaan pangan dan gizi keluarga.

\section{METODE PELAKSANAAN}

Kegiatan ini berlangsung selama 3 bulan mulai dari tanggal 26 Mei sampai 27 Agustus tahun 2021 di Dusun II Desa Petudua Kecamatan Tanggetada Kabupaten Kolaka Provinsi Sulawesi Tenggara. Pendampingan dilakukan terhadap 10 Keluarga yang masing-masing telah memperoleh benih tanaman hortikultura khususnya olerikultura dari pemerintah Desa Petudua. Masing-masing pengabdi mendampingi 2-3 keluarga, mulai dari awal sampai kegiatan pengabdian selesai.

Tahapan kegiatan meliputi : 1) penyuluhan tentang cara budidaya tanaman hortikultura khususnya olerikutura, 2) pelatihan cara menyemaikan bibit, 3) pelatihan pembuatan pupuk organik dan pestisida organik dan 4) evaluasi kegiatan. Alat-alat yang diperlukan untuk pembibitan yakni pot tray, sedangkan bahan-bahan yang digunakan adalah tanah, pupuk 
kandang, benih tanaman dan air. Alat-alat yang digunakan dalam pembuatan pestisida organik dan pupuk organik adalah ember tertutup atau toples, saringan, dan hand sprayer. Bahan-bahan yang digunakan adalah kulit bawang merah, kulit bawang putih, dan air.

\section{HASIL DAN PEMBAHASAN}

\section{Penyuluhan Tentang Manfaat Budidaya Tanaman Di Pekarangan}

Kegiatan ini dilaksanakan dirumah salah satu kepala keluarga, pada tanggal 26 Mei 2021. Peserta kegiatan didominasi oleh ibu-ibu, karena merekalah yang paling berperan dalam memanfaatkan pekarangan. Materi yang disampaikan pada kegiatan ini terkait dengan manfaat budidaya tanaman di pekarangan, pengertian tanaman olerikultura, serta cara budidayanya.

Manfaat budidaya tanaman sayuran di pekarangan dapat memberikan tiga manfaat sekaligus yakni meningkatkan nilai konservasi lingkungan, nilai ekonomi dan nilai ketahanan pangan. Peningkatan nilai konservasi karena dapat berfungsi sebagai daerah resapan air sehingga setiap rumah tangga mampu melakukan konservasi air yang akan menjadi cadangan kebutuhan air pada musim kemarau. Pemanfaatan pekarangan juga mampu meningkatkan nilai ekonomi masyarakat melalui wirausaha agribisnis.Penanaman tanaman hortikultura seperti sayuran, bumbu dapur, buah-buahan dan tanaman obat-obatan dapat menguntungkan secara ekonomi bagi keluarga. Jika dilakukan secara intensif, maka kebutuhan rumah tangga setiap hari akan tercukupi tanpa harus mengeluarkan biaya untuk membeli dari luar, bahkan sebagian hasilnya dapat dijual untuk memenuhi kebutuhan pokok lainnya. Selain itu, biaya yang dibutuhkan untuk pengolahan lahan pekarangan pun sangat ekonomis melalui penerapan teknologi yang sederhana (Sugiarso et al, 2017). Dengan demikian, ketahanan pangan dan gizi keluarga pun tetap terjamin.

Kegiatan penyuluhan ini dapat meningkatkan pemahaman masyarakat khususnya di Dusun II Desa Petudua tentang manfaat budidaya tanaman di pekarangan rumah masingmasing untuk dapat memenuhi kebutuhan pangan sehari-hari, bahkan dapat menjadi sumber pendapatan keluarga (Musa et al, 2020). Selain itu, pengetahuan masyarakat juga tentang cara budidaya tanaman yang baik dapat meningkat, sehingga dapat memberikan hasil yang baik. Masyarakat pun dapat mengetahui cara pembuatan pupuk dan pestisida organik, dari bahanbahan yang ada di lingkungan masyarakat itu sendiri.

\section{Pelatihan Cara Menyemaikan Bibit Sayuran}

Pelatihan menyemaikan beberapa jenis bibit tanaman olerikultura dilakukan pada pekarangan rumah masing-masing keluarga. Kegiatan dimulai dengan mempersiapkan media tanam berupa campuran tanah dan pupuk kandang dengan perbandingan 1:1. Campuran media tanam yang baik berbagai jenis tanaman hortikultura adalah campuran top soil dengan pupuk kandang (Maysari, 2019). Pupuk kandang yang digunakan adalah kotoran kambing, karena mudah diperoleh di Desa ini.

Kegiatan selanjutnya adalah pembibitan beberapa jenis tanaman yang memiliki benih berukuran kecil, diantaranya sawi, cabai, tomat, dan terong. Sedangkan kangkung, paria, jagung manis, dan bayam dapat ditanam langsung ke dalam tanah. Pembibitan dilakukan menggunakan tray semai 200 lubang. Cara melakukan pembibitan adalah sebagai berikut :

1. Tray semai diisi dengan campuran tanah, pupuk kandang kambing dan sekam;

2. Setelah terisi penuh, dibuat lubang kecil sedalam $0,5 \mathrm{~cm}$ dengan menggunakan tusuk gigi atau lidi;

3. Benih tanaman kemudian dimasukkan ke dalam lubang tersebut, 1 biji 1 lubang;

4. Setelah semua terisi, lubang kemudian ditutup tipis dengan menggunakan pupuk kandang;

5. Lakukan penyiraman dengan menggunakan hand sprayer.

Setelah penyemaian bibit tanaman selesai, masyarakat diajarkan lagi tentang cara pindah tanam tanaman, cara membersihkan gulma, serta cara pemupukan tanaman serta perawatan 
tanaman lainnya. Manfaat yang dapat diperoleh dari kegiatan ini adalah masyarakat akan mudah memahami cara menyemaikan bibit dengan baik, sehingga dapat mengaplikasikan pada lahan pekarangan masing-masing.

\section{Pelatihan Pembuatan Pupuk Organik dan Pestisida Organik}

Masyarakat di Dusun II Desa Petudua belum mengetahui manfaat pupuk organik dan pestisida organik, serta bahan-bahan yang dapat dimanfaatkan dalam pembuatan pupuk dan pestisida organik tersebut. Pelatihan ini bertujuan untuk mengolah dan memanfaatkan limbah rumah tangga, sehingga tidak perlu lagi mengeluarkan biaya untuk membeli pupuk ataupun pestisida. Salah satu bahan yang sangat mudah diperoleh berasal dari limbah rumah tangga yakni kulit bawang merah dan bawang putih. Kulit bawang sering dianggap tidak berguna dan dibuang begitu saja, sehingga menyebabkan pencemaran lingkungan (Rinzani et al, 2020). Kulit bawang ini memiliki tiga keunggulan sekaligus yakni, sebagai zat pengatur tumbuh, pupuk organik, dan pestisida organik, serta sangat mudah dalam pembuatannya (Rahmawati, 2020). Sehingga dilakukan pelatihan mengenai cara pembuatan pupuk dan pestisida organik dari kulit bawang. Pelatihan dilakukan di salah satu rumah warga yaitu bapak David, dan dihadiri oleh beberapa warga lainnya yang berada di dusun tersebut.

Proses pembuatan pupuk dan pestisida organik dari kulit bawang ini sangat muda dan menggunakan peralatan yang sederhana, sehingga masyarakat mampu melakukannya dirumah masing-masing. Tahap-tahap pembuatan pupuk dan pestisida organik dari kulit bawang adalah sebagai berikut :

1) Kulit bawang merah dan bawang putih dikumpulkan dari beberapa rumah warga. Kulit bawang yang akan digunakan adalah yang bersih dan bebas dari penyakit, serta tidak berwarna kehitaman;

2) Setelah dibersihkan, kulit bawang tersebut dimasukkan ke dalam wadah tertutup, seperti ember, toples atau botol kemasan air mineral;

3) Lalu tambahkan dengan air;

4) Wadah kemudian ditutup dan disimpan selama 24 jam.

5) Apabila akan diaplikasikan ke tanaman, kulit bawang tersebut disaring lalu disiramkan pada tanaman (Maulana, 2021). Cara pembuatannya juga dapat diakses pada kanal youtube DOSEN TANI melalui link berikut https://youtu.be/kqIpmf8oZrc .

Manfaat yang diperoleh dari kegiatan ini adalah menambah pengetahuan masyarakat tentang bahan-bahan yang dapat digunakan sebagai pupuk dan pestisida organik yang sangat mudah diperoleh dan berada di sekitar kita. Masyarakat pun dapat mengetahui manfaat kulit bawang merah dan bawang putih sebagai pupuk organik, pestisida organik dan ZPT yang selama ini hanya dianggap sebagai limbah rumah tangga yang tidak bermanfaat, sehingga dibuang begitu saja. Selama mengikuti proses pembuatan pupuk organik sekaligus pestisida organik ini, masyarakat di Dusun II Desa Petudua sangat bersemangat, dan aktif mengajukan pertanyaan kepada tim pengabdi.
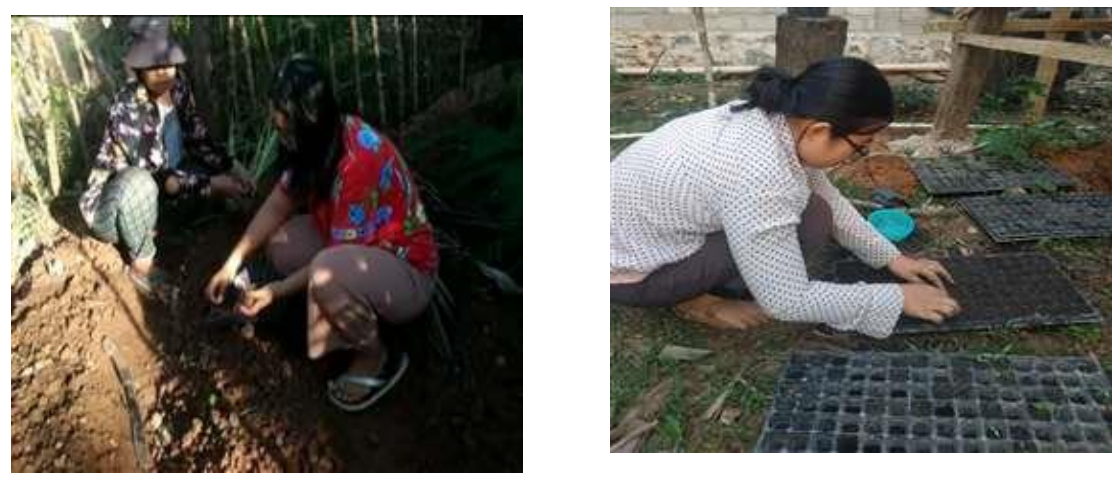

Gambar 1. Pelatihan cara menyemaikan benih tanaman 


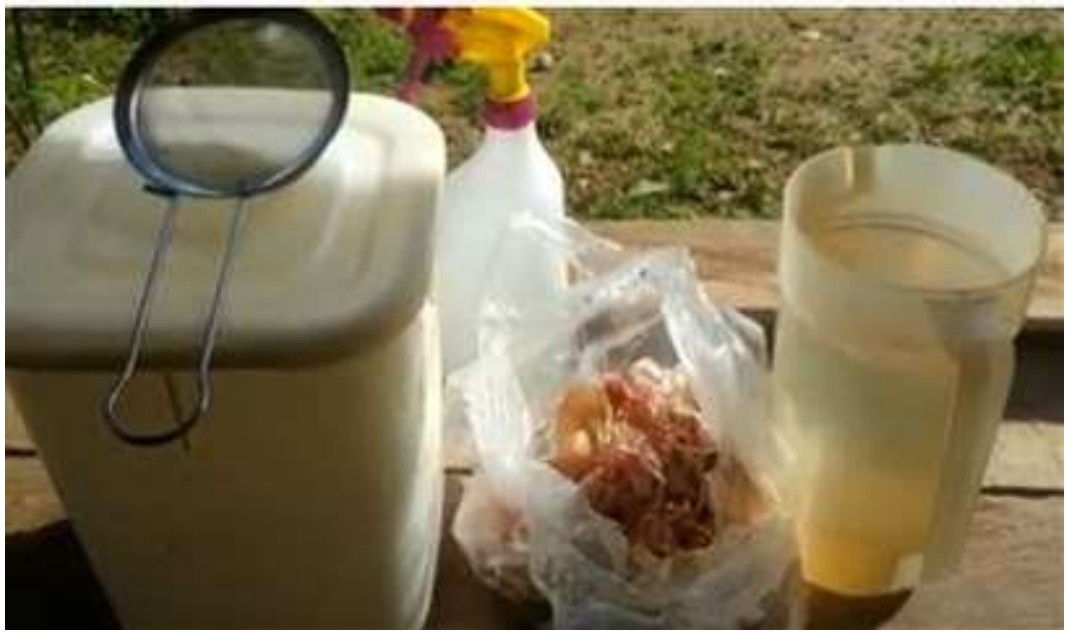

Gambar 2. Alat dan bahan pembuatan pupuk dan pestisida organik

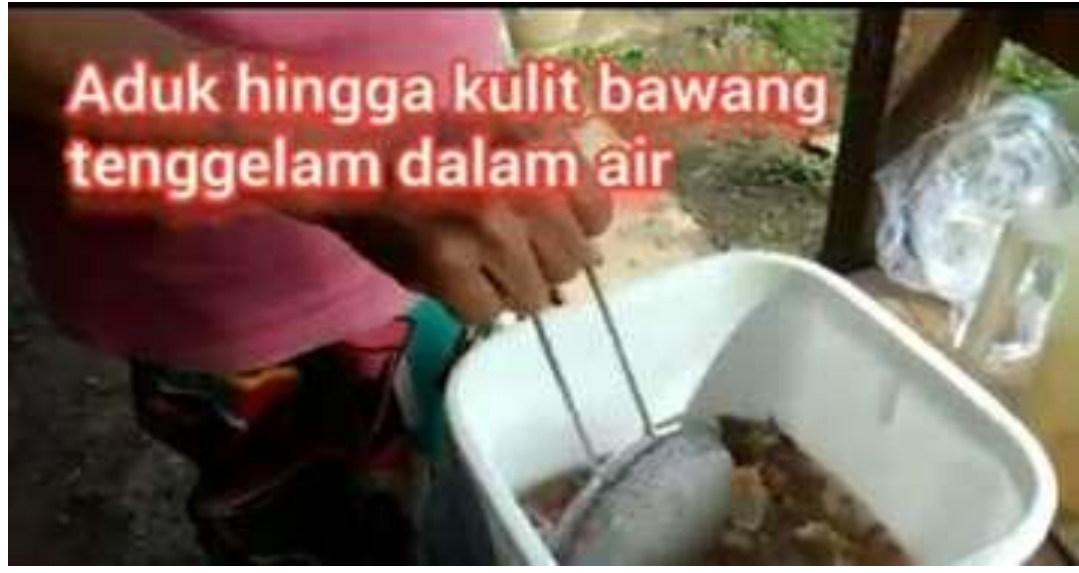

Gambar 3. Proses pembuatan pupuk dan pestisida organik dari kulit bawang
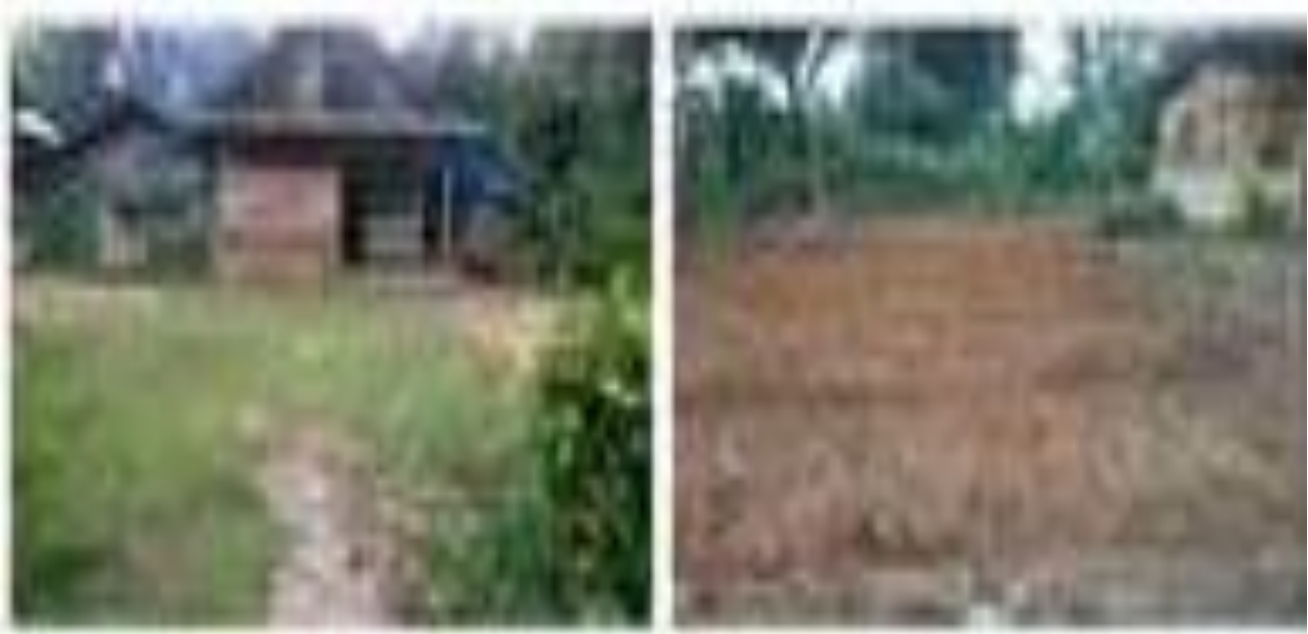

Gambar 4. Kondisi pekarangan sebelum diolah 


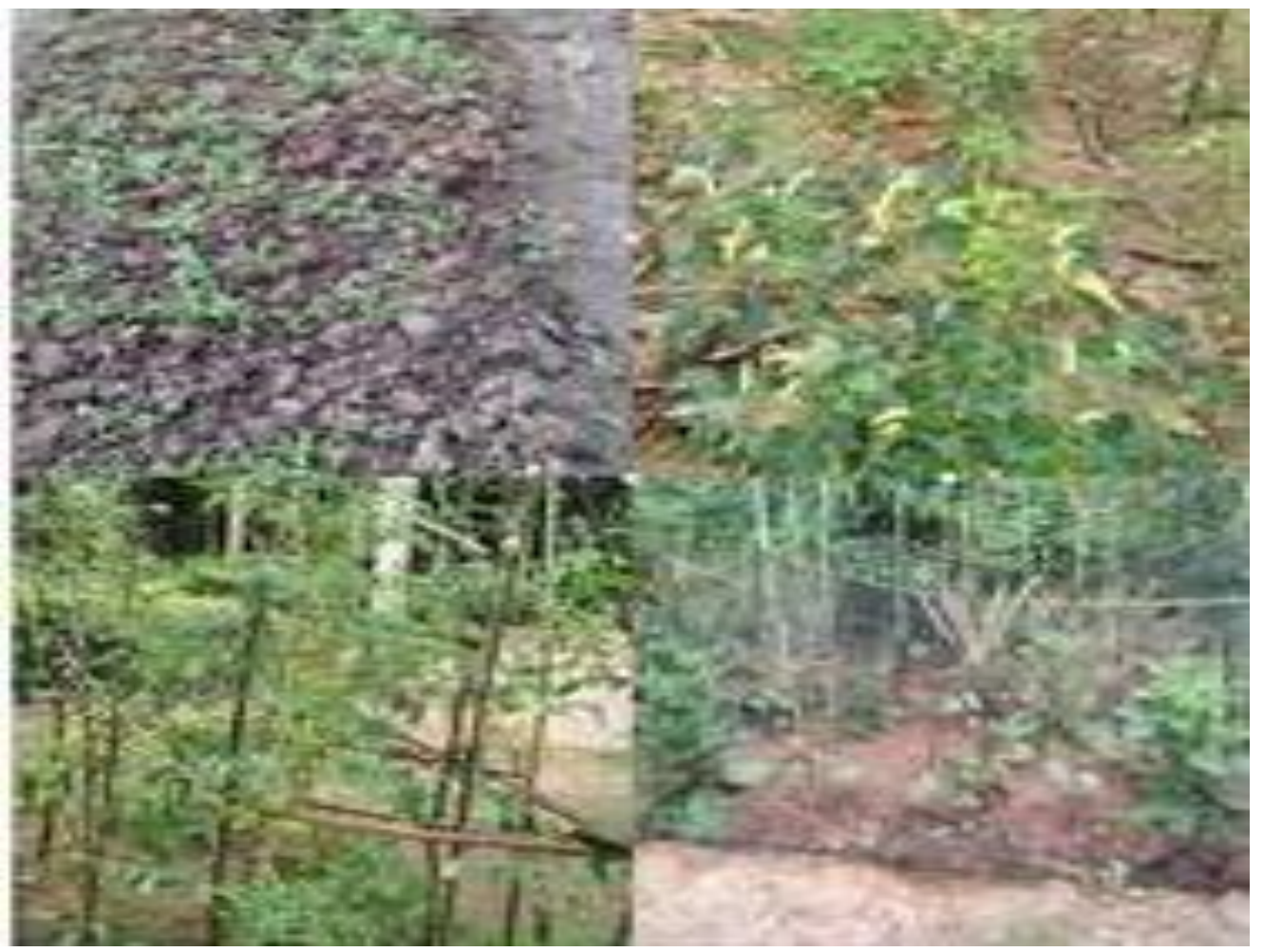

Gambar 5. Kondisi pekarangan sesudah diolah

\section{SIMPULAN DAN TINDAK LANJUT}

Pemanfaatan pekarangan untuk budidaya tanaman olerikultura merupakan salah satu solusi yang tepat untuk mendukung ketahanan pangan pada masa pandemi Covid-19 saat ini. Lahan pekarangan yang dimiliki oleh masyarakat Desa Petudua kini telah dimanfaatkan dengan baik. Masyarakat berlomba-lomba untuk menanam sayur-sayuran, karena telah merasakan manfaat yang sangat besar dari pekarangan mereka yakni dapat menikmati sayuran segar tiap hari dan juga menikmati hasil penjualan sayuran tersebut. Pemerintah Desa pun mengapresiasi dengan memberikan ongkos harian $(\mathrm{OH})$ bagi masyarakat yang tanamannya berhasil.

Pemerintah Desa Petudua diharapkan untuk tetap melanjutkan program ini, agar masyarakat dapat terus memanfaatkan lahan pekarangan dengan baik. Selain itu, edukasi tentang cara budidaya tanaman yang baik sangat perlu diberikan kepada masyarakat, agar dapat memberikan hasil yang maksimal.

\section{DAFTAR PUSTAKA}

Aisyah, I. S. (2020). Ketahanan Pangan Keluarga di Masa Pandemi Covid-19. Jurnal Kesehatan Komunitas Indonesia, 16(2), 179-189.

Alhudhori, M. (2017). Optimalisasi Pemanfaatan Pekarangan. Jurnal Ilmiah Universitas Batanghari Jambi, 17(1), 237-149. http://dx.doi.org/10.33087/jiubj.v17i1.171

Ashari, Saptana, \& Purwanti, T.B. (2012). Potensi dan Prospek Pemanfaatan Lahan Pekarangan Untuk Mendukung Ketahanan Pangan. Forum Penelitian Agro Ekonomi, 30(1), 13-30.

Dwiratna, N.P.S., Widyasanti, A., \& Rahmah, D. (2016). Pemanfaatan Lahan Pekarangan Dengan Menerapkan Konsep Kawasan Rumah Pangan Lestari. Dharmakarya : Jurnal Aplikasi $\begin{array}{llllll}\text { Ipteks Untuk } \quad \text { Masyarakat, } & \text { 5(1), } & 19 & -\end{array}$ https://doi.org/10.24198/dharmakarya.v5i1.8873

Khomah, I dan Rhina, U.F. (2016). Potensi dan Prospek Pemanfaatan Lahan Pekarangan Terhadap Pendapatan Rumah Tangga. Proceeding Seminar Nasional Peningkatan Kapabilitas UMKM Dalam Mewujudkan UMKM Naik Kelas, 155-156. 
Madyowati, S.O. (2017). Sosialisasi Pengisian Buku Catatan Pemanfaatan Pekarangan/Hatinya PKK (Peternakan, Perikanan, Warung Hidup, Lumbung Hidup, TOGA, Tanaman Keras. Laporan Akhir Pengabdian Masyarakat. Surabaya: Universitas Dr. Sutomo.

Maulana, A.H. (2021). 7 Manfaat Kulit Bawang Merah Untuk Tanaman dan Pengaplikasiannya. $\begin{array}{lllll}\text { Kompas.com } & 26 . & \text { Diakses } & 12 & \text { Oktober }\end{array}$ https://www.kompas.com/homey/read/2021/07/21/221100476/7-manfaat-kulitbawang-merah-untuk-tanaman-dan-cara-pengaplikasiannya?page=all

Musa, N., Nurdin, Yunnita, F. (2020). Pemanfaatan Lahan Kosong dan Pekarangan Melalui Pemberdayaan Petani Hortikultura di Desa Huntu Barat Kabupaten Bone Bolango. Jurnal Abdi Insani Universitas Mataram, 7(3), 346-353.

Rahmawati, D. (2020). Pemanfaatan Kulit Bawang Merah Untuk Tanaman. Diakses 12 Oktober 2021 http://cybex.pertanian.go.id/mobile/artikel/94229/Pemanfaatan-kulit-bawangmerah-untuk-tanaman.

Rinzani, F., Siswoyo, dan Azhar. (2020). Pemanfaatan Limbah Kulit Bawang Merah Sebagai Pupuk Organik Cair Pada Budidaya Tanaman Bayam di Kelurahan Benteng Kecamatan Ciamis Kabupaten Ciamis. Jurnal Inovasi Penelitian, 1(3), 197-206.

Sekarindah, T. (2008). Terapi Jus Buah dan Sayur. Puspa Swara. Jakarta.

Simanjuntak, A. H., \& Erwinsyah, R. G. (2020). Kesejahteraan Petani dan Ketahanan pangan pada masa pandemi Covid-19 telaah Kritis Terhadap Rencana Megaproyek Lumbung Pangan Nasional Indonesia. Sosio Informa, 6(02), 184-204.

Solihin, E., Apong, S., Wawan, K. (2018). Pemanfaatan Pekarangan Rumah Untuk Budidaya Sayuran Sebagai Penyedia Gizi Sehat Keluarga. Jurnal Pengabdian Kepada Masyarakat, 2(8), 590-593.

Sugiarso, Agus, R., Rusmadi. (2017). Pemberdayaan Masyarakat Melalui Pemanfaatan Tanah Pekarangan (PTP) Untuk Konservasi dan Wirausaha Agribisnis di Kelurahan Kedung Pane Kota Semarang. Jurnal DIMAS, 17(2), 343-366.

Maysari, R. (2019). Membuat Media Persemaian. Diakses 15 Oktober 2021

http://cybex.pertanian.go.id/mobile/artikel/82891/MEMBUAT-MEDIA-PERSEMAIAN/ 